\title{
Updating the evidence base for suctioning adult patients: A systematic review
}

\author{
Tom J Overend BScPT PhD ${ }^{1}$, Cathy M Anderson BHScPT MSc², Dina Brooks BScPT PhD ${ }^{3}$, Lisa Cicutto BScN PhD ${ }^{4}$, \\ Michael Keim RRT ${ }^{5}$, Debra McAuslan BScN MScN ${ }^{6}$, Mika Nonoyama RRT PhD $^{7}$
}

\author{
TJ Overend, CM Anderson, D Brooks, et al. Updating the evidence \\ base for suctioning adult patients: A systematic review. Can Respir J \\ 2009;16(3):e6-e17.
}

OBJECTIVES: To update a previous clinical practice guideline on suctioning in adult patients, published in the Canadian Respiratory Journal in 2001.

METHODS: A primary search of the MEDLINE (from 1998), CINAHL, EMBASE and The Cochrane Library (all from 1996) databases up to November 2007, was conducted. These dates reflect the search limits reached in the previous clinical practice guideline. A secondary search of the reference lists of retrieved articles was also performed. Two reviewers independently appraised each study before meeting to reach consensus. Study quality was evaluated using the Jadad and PEDro scales. When sufficient data were available, a meta-analysis was conducted using a random effects model. Data are reported as ORs, weighted mean differences and $95 \%$ CIs. When no comparisons were possible, qualitative analyses of the data were completed.

RESULTS: Eighty-one studies were critically appraised from a pool of 123. A total of 28 randomized controlled trials or randomized crossover studies were accepted for inclusion. Meta-analysis was possible for open versus closed suctioning only. Recommendations from 2001 with respect to hyperoxygenation, hyperinflation, use of a ventilator circuit adaptor and subglottic suctioning were confirmed. New evidence was identified with respect to indications for suctioning, open suction versus closed suction systems, use of medications and infection control.

CONCLUSIONS: While new evidence continues to be varied in strength, and is still lacking in some areas of suctioning practice, the evidence base has improved since 2001. Members of the health care team should incorporate this evidence into their practice.

Key Words: Adult; Airway; Endotracheal; Suction; Systematic review

$\mathrm{S}_{\mathrm{s}}^{\mathrm{u}}$ ctioning is a procedure used to remove substances from the trachea, pharynx, nose or mouth either through a natural orifice (nose or mouth) or artificial tubing (endotracheal tube, tracheostomy tube, nasal or oral airway). Physiotherapists, respiratory therapists, nurses and physicians use suctioning to promote secretion clearance (pulmonary hygiene) and/or maintain a patent airway. The technique is used in patients along the continuum of care from the critically ill to individuals living in the community.

Four major reviews related to suctioning have been published. The American Association of Respiratory Care provided guidelines for suctioning mechanically ventilated patients

\section{Le point sur les preuves relatives à l'aspiration trachéale chez les patients adultes : Revue systématique}

OBJECTIF : Mettre à jour une directive de pratique clinique sur l'aspiration trachéale chez les patients adultes, publiée dans la Revue canadienne de pneumologie en 2001.

MÉTHODE : Les auteurs ont procédé à une première interrogation du réseau MEDLINE (à partir de 1998), des bases de données CINAHL et EMBASE et du registre Cochrane (à partir de 1996) jusqu'à mai 2007. Ces dates coïncident avec la fin de la période d'interrogation des sources pour la version antérieure de la directive. Une deuxième interrogation a été réalisée à partir des listes bibliographiques des articles recensés. Deux examinateurs indépendants ont évalué chaque étude avant de parvenir à un consensus. Ils ont établi la qualité des études à l'aide des échelles Jadad et PEDro. Une fois les données suffisantes réunies, une méta-analyse a été réalisée à l'aide d'un modèle à effets aléatoires. Les données sont présentées sous forme de rapports des cotes, de différences moyennes pondérées et d'IC à 95 \%. Lorsqu'il était impossible de procéder à des comparaisons, des analyses qualitatives des données ont été effectuées.

RÉSULTATS : Quatre-vingt-une études sur 123 ont été évaluées de façon critique. En tout, 28 études randomisées et contrôlées ou études randomisées avec permutation des groupes ont été incluses. Il a été possible de réaliser une méta-analyse uniquement pour les comparaisons entre aspiration en circuit ouvert ou fermé. En ce qui concerne l'hyperoxygénation, l'hyperinflation, l'utilisation d'un adaptateur de circuit du respirateur et l'aspiration sous-glottique, les recommandations de 2001 ont été confirmées. De nouvelles preuves ont été recueillies relativement aux indications de l'aspiration, de l'aspiration en circuit ouvert versus fermé, de l'utilisation de médicaments et de la lutte contre l'infection.

CONCLUSION : Bien que leur solidité continue d'être variable et qu'il en manque certaines pour divers aspects de la technique d'aspiration, les preuves récentes sont meilleures que celles de 2001 et les membres des équipes soignantes sont invités à les intégrer à leur pratique.

(1) and suctioning of the patient in the home (2), while the Joanna Briggs Institute in Australia published a systematic review of tracheal suctioning for adults with an artificial airway (3). The most recent systematic review, conducted by Brooks et al (4), was completed in the late 1990s and published in 2001 as a clinical practice guideline (CPG) for suctioning the airway of the intubated and nonintubated patient. These reviews did not consistently use a structured, critical appraisal approach, and while the Brooks et al (4) review featured the most rigorous evaluation, all of these reviews are now outdated, with the latest literature searched only up to the late 1990s.

${ }^{1}$ School of Physical Therapy, University of Western Ontario; ${ }^{2}$ London Health Sciences Centre, London; ${ }^{3}$ Department of Physical Therapy,

University of Toronto, Toronto, Ontario; ${ }^{4}$ Department of Medicine, National Jewish Center for Medicine and Research, Denver, Colorado,

USA; ${ }^{5}$ Respiratory Therapy Services, St Joseph's Health Care; ${ }^{6}$ London Health Sciences Centre, London; ${ }^{7}$ Toronto Rehabilitation Institute,

Toronto, Ontario

Correspondence: Dr Tom J Overend, School of Physical Therapy, The University of Western Ontario, London, Ontario N6G 1 H1.

Telephone 519-661-2111 ext 88850, fax 519-661-3866, e-mail toverend@uwo.ca 
Given the concerns of previous reviews, and the numerous gaps in the evidence on suctioning, there is a need to systematically review the recent literature regarding this technique. Thus, the purpose of the present article was to systematically review the literature pertaining to suctioning of the airway in both intubated and nonintubated adult patients published since the Brooks et al (4) study. We had two main research questions:

1. What are the clinical indications and precautions for suctioning adult patients?; and

2. What is the evidence for the methods and techniques that optimize benefits and reduce complications or risks when suctioning intubated, nonintubated or tracheotomized adult patients?

\section{METHODS}

\section{Search strategy}

A search strategy was developed with the assistance of a university research librarian. The electronic databases MEDLINE (from 1998), CINAHL, EMBASE and The Cochrane Library (all from 1996) were searched up to November 2007. The start dates reflect the literature search limits reached in the Brooks et al (4) CPG. Key words included "suction", along with "airway", "trachea", "pharynx" (and variants "oro-" and "nasopharynx"), "subglottic", "oxygenation" (and variants "hyper-oxygenation" and "preoxygenation"), "insufflation", "endotracheal" and "tracheostomy". These are essentially the same terms that were used by Brooks et al (4) in their CPG.

A secondary search of the reference lists in all retrieved articles was also conducted. Papers were identified for potential review if their titles suggested relevance to either of our research questions.

\section{Selection of articles}

All English language studies conducted with adult patients (18 years or older), published since 1998 (MEDLINE) or 1996 (CINAHL, The Cochrane Library, EMBASE) were selected. The selection converged on the strongest sources of evidence: randomized controlled trials (RCTs) or randomized crossover (RCO) study designs. However, to obtain information on all aspects of suctioning (eg, harms, infection control), we also reviewed a variety of low-level experimental designs (ie, nonrandomized trials, case reports) to provide evidence for topics in which no high-level studies were available.

A title and abstract review of the initial search results was performed independently by two reviewers who then met to reach consensus on which full articles were potentially eligible for review. If abstracts were not available, full articles were selected based on their titles.

\section{Data extraction}

The research team was divided into three pairs for critical appraisal of the papers. Two reviewers independently extracted all of the data from each selected trial using a predefined form modified from forms used previously $(5,6)$. The extracted data included general information about the studies (eg, eligibility criteria, study design), quality assessment including randomization, participant dropout and withdrawals, and description of participants, groups and/or interventions, outcome measures and results. The two reviewers were able to reach consensus regarding the data extracted for all studies. Attempts were made to contact four authors to obtain additional or missing data, and randomization information and data (7-10). Two responses were received $(7,8)$.

\section{Quality assessment}

Each pair of reviewers independently assessed the quality of each study before meeting to reach consensus. They considered the sources of bias that have a major influence on the magnitude of effect size in clinical trials such as unconcealed randomization, blinding, dropouts and withdrawals. The quality of each study was rated using formal quality scores according to two scales: a 0 to 5 scale developed by Jadad et al (11), and the 0 to 10 scale used in the Physiotherapy Evidence Database (PEDro) suggested by Maher et al (12). The scores presented in the present report represent the consensus of the two reviewers for each scale. Higher scores indicate higher quality. Agreement between reviewers was measured using the kappa statistic $(13,14)$. SAS software (version 9.1.3, SAS Institute Inc, USA) was used for kappa calculations.

\section{Analysis and interpretation}

Descriptive data were summarized in tables that included information on study characteristics, groups/interventions, outcome measures and a summary of main results.

There were enough high-quality papers regarding open suction (OS) versus closed suction (CS) to combine for metaanalysis (with the Cochrane Collaboration's Review Manager 4.2 software) using a random effects model on certain outcome measures. Meta-analyses were not performed for other outcome measures because of large heterogeneity in the groups or interventions, and the outcome measures. Thus, a qualitative analysis of the literature with summaries based on the new evidence published since the Brooks et al (4) review was also completed.

\section{RESULTS AND DISCUSSION}

The primary literature search of the four databases yielded 302 citations. After eliminating duplications, 123 citations were screened for possible review, of which 81 papers received full review. Thirty-two papers were identified from the secondary search; 10 of these were screened and five received full review. In total, $15 \mathrm{RCT}$ s and $13 \mathrm{RCO}$ studies were accepted following review. Information from these studies is presented in Tables 1 to 7 . Also included is information from 11 low-level studies to fill in gaps and provide the 'best available evidence' for topics in which there were no randomized studies. It should be noted that almost all of the evidence included relates to the suctioning of intubated patients; there is very little information available regarding the use of this technique in nonintubated patients.

There was good agreement between reviewers on both the Jadad scale (11) (kappa score $0.89 ; 95 \%$ CI 0.74 to 1.00 ) and the PEDro scale (12) (kappa 0.90; 95\% CI 0.80 to 1.00 ). Mean quality scores for the 28 included articles were 2.04 (out of 5) on the Jadad scale and 6.21 (out of 10) on the PEDro scale. The most frequent scores were 2 (range 1 to 5; $\mathrm{n}=17$ ) for the Jadad scale, and 6 (range 4 to 9; $\mathrm{n}=11$ ) for the PEDro scale. The most common internal validity errors for 
the Jadad scale were reporting an appropriate method of randomization and describing the study as a double-blind design. For the PEDro scale, the most frequently missed items were concealing the treatment allocation and blinding of subjects, caregivers and outcome measure assessors. It is difficult to conduct double-blind studies in which the interventions are generally easily differentiated by the patients and caregivers (eg, OS versus CS).

\section{First research question}

What are the clinical indications and precautions for suctioning adult patients?

Indications for suctioning: Our first research question examined the precautions and clinical indications for suctioning. Only one new study was identified. Predictors of retained secretions were examined in a prospective observational study (15) on 66 patients requiring mechanical ventilation (MV). A sawtooth pattern on a flow-volume loop (seen on the ventilator screen) and respiratory sounds over the trachea had likelihood ratios of a positive test (presence of secretions greater than $0.5 \mathrm{~mL}$ ) of 2.70 and 2.50, respectively, and likelihood ratios of a negative test of 0.25 and 0.45 , respectively. When these two parameters were both present, the likelihood ratio for a positive test was increased to 14.7 , while the negative test did not have an appreciable change (0.42) (15).

Summary: For patients on MV, the best available evidence suggests the presence of retained secretions if a sawtooth pattern and/or respiratory sounds over the trachea are present.

\section{Second research question}

What is the evidence for the methods and techniques that optimize benefits and reduce complications or risks when suctioning intubated, nonintubated or tracheotomized adult patients?

The following sections of the Results and Discussion are organized according to how the pool of new literature was categorized. It should be noted that all of the new evidence is derived from papers that either studied patients on MV or in a few cases, used a lung model. No papers that studied nonintubated patients were found.

\section{Hyperoxygenation}

Hyperoxygenation is the practice of increasing the oxygen concentration (typically to 100\%) for a short period before and, in some cases, after suctioning. The $2001 \mathrm{CPG}$ recommended that hyperoxygenation should be used before and after suctioning to prevent oxygen desaturation in mechanically ventilated patients who underwent trauma, or had cardiac or chronic obstructive pulmonary disease (COPD) (4). Only one new study regarding the effect of hyperoxygenation was found (9). This study compared no hyperoxygenation with supplying oxygen for $1 \mathrm{~min}$ before and after CS in 30 patients in the intensive care unit (ICU) who required MV. It was not clear whether the order of the interventions was randomized, and the request for information from the authors was unsuccessful. Hyperoxygenation resulted in higher levels of aterial oxygen saturation $\left(\mathrm{SaO}_{2}\right)$ and pressure of arterial oxygen $\left(\mathrm{PaO}_{2}\right)$, with no adverse effects.

Summary: For patients on MV, the new evidence continues to support the use of hyperoxygenation before and after suctioning to maintain oxygenation levels.

\section{Hyperinflation}

Hyperinflation is the practice of adding extra volume to the lungs, either via a ventilator or a manual resuscitation bag, before suctioning. In the $2001 \mathrm{CPG}$ (4), the use of hyperinflation was not recommended as a means to improve oxygenation in preoxygenated patients following coronary artery bypass surgery. One new RCT (16) examined the issue of hyperinflation (Table 1). Barker and Adams (16) reported no effect of hyperinflation on oxygenation, heart rate (HR), blood pressure, mixed venous oxygen saturation $\left(\mathrm{SvO}_{2}\right)$ and dynamic compliance following OS in 17 preoxygenated patients with acute lung injury who received pressure support ventilation. Hyperinflation also did not reverse the effects of disconnection from the ventilator during endotracheal suctioning. The authors noted that disconnection from MV in patients with acute lung injury may result in significant derecruitment of the lungs.

Two new RCO studies (17) investigated the effect of hyperinflation on other variables (Table 1). Choi and Jones (17) examined the effect of manual hyperinflation on static lung compliance and airway resistance in 15 ICU patients with ventilator-associated pneumonia (VAP). Hyperinflation improved lung compliance and decreased airway resistance for up to 30 min following suction. The second study (18) investigated the effect of manual versus ventilator hyperinflation on sputum wet weight and static compliance in 20 ICU patients who required MV. There was no difference in sputum weight, but both methods of hyperinflation improved static compliance following suction.

Summary: For mechanically ventilated patients, the new evidence supports the previous recommendation of not to use hyperinflation to improve oxygenation. However, manual or ventilator hyperinflation may result in increased lung compliance in patients on $\mathrm{MV}$, and manual hyperinflation may decrease airway resistance in patients with VAP. The clinical implications of these physiological changes are unclear.

\section{Use of an adaptor in the ventilator circuit}

An adaptor is a device added to a ventilator circuit to allow for suctioning without disconnecting the patient from the ventilator. In the $2001 \mathrm{CPG}$ (4), the use of an adaptor that allowed the continuation of MV for the duration of the suctioning procedure was preferred over disconnection from the ventilator if no access to hyperinflation or hyperoxygenation was available. Suctioning through an adaptor was as effective as disconnecting the ventilator circuit and providing hyperoxygenation before and after suction. One new study (19) has examined the effect of an adaptor with hyperoxygenation (Table 1). Metz et al (19) evaluated the effect of a close-fitted adaptor with intermittent endotracheal tube (ETT) clamping and pressure-controlled hyperinflation after suction in an RCO study of 16 patients requiring MV for respiratory failure. Offventilator suction resulted in a decrease in $\mathrm{PaO}_{2}$ (from baseline values) for up to $60 \mathrm{~min}$, while suctioning through an adaptor resulted in an increase in $\mathrm{PaO}_{2}$. Between-group differences from raw data reported in the paper by Metz et al (19) were calculated by our group. Suctioning through an adaptor resulted in significantly higher $\mathrm{PaO}_{2}$ values for up to $1 \mathrm{~h}$ postsuction compared with off-ventilator suction.

Summary: The new evidence continues to support the use of an adaptor for suctioning to maintain oxygenation in mechanically ventilated patients. 
TABLE 1

Summary of randomized studies on hyperinflation

\begin{tabular}{|c|c|c|c|}
\hline $\begin{array}{l}\text { Author (reference), } \\
\text { study design }\end{array}$ & Description of groups and interventions & Outcome measures & Summary of main results \\
\hline $\begin{array}{l}\text { Barker and Adams (16), } \\
\text { RCT }\end{array}$ & $\begin{array}{l}\text { Sample: Patients in ICU with ALI requiring MV } \\
\text { (pressure support) ( } n=17) \\
\text { Group } 1(n=5) \text { : OS in supine with } 30^{\circ} \text { elevation } \\
\text { Group } 2(n=5) \text { : OS in } A S L \text { with } 0^{\circ} \text { elevation } \\
\text { Group } 3(n=7) \text { : OS with manual hyperinflation } \\
\text { in ASL }\left(0^{\circ} \text { elevation) }\right. \\
\text { All patients were hyperoxygenated }\end{array}$ & $\begin{array}{l}\mathrm{PaO}_{2} \\
\mathrm{PaCO}_{2} \\
\text { Heart rate } \\
\text { Blood pressure } \\
\mathrm{SvO}_{2} \\
\text { Dynamic compliance }\end{array}$ & $\begin{array}{l}\text { No significant difference between groups } \\
\text { for any outcome measure } \\
\text { Disconnection of patients with ALI from } \\
\text { MV can result in significant derecruit- } \\
\text { ment of the lungs. The use of manual } \\
\text { hyperinflation does not appear to } \\
\text { override the loss of PEEP and the } \\
\text { derecruitment effects }\end{array}$ \\
\hline $\begin{array}{l}\text { Choi and Jones (17), } \\
\text { RCO }\end{array}$ & $\begin{array}{l}\text { Sample: Patients with VAP on MV }(\mathrm{n}=15) \\
\text { Intervention 1: OS with manual } \\
\text { hyperinflation } \\
\text { Intervention 2: OS alone }\end{array}$ & $\begin{array}{l}\text { Static lung compliance } \\
\text { Airway resistance }\end{array}$ & $\begin{array}{l}\text { Compliance was greater with intervention } 1 \\
\text { immediately and } 30 \text { min after suctioning } \\
(P<0.001) \text {. Lower airway resistance with } \\
\text { intervention } 1 \text { up to } 30 \text { min }(P=0.02)\end{array}$ \\
\hline $\begin{array}{l}\text { Berney and Denehy (18), } \\
\text { RCO }\end{array}$ & $\begin{array}{l}\text { Sample: Patients in ICU requiring MV }(\mathrm{n}=20) \\
\text { Intervention } 1 \text { : OS, foot of the bed elevated to } \\
35^{\circ}-45^{\circ} \text {, six sets of } 6 \text { manual hyperinflation } \\
\text { breaths } \\
\text { Intervention 2: OS, ventilator hyperinflation } \\
\text { All patients received six sets of } 6 \text { hyperinflations } \\
\text { with } 30 \mathrm{~s} \text { of } \mathrm{V}_{\mathrm{T}} \text { breathing between sets } \\
\text { Suctioned after every second set }\end{array}$ & $\begin{array}{l}\text { Sputum wet weight } \\
\text { Static lung compliance }\end{array}$ & $\begin{array}{l}\text { No significant difference in the sputum } \\
\text { weight between interventions. } \\
\text { Both interventions improved pulmonary } \\
\text { compliance }(P<0.001)\end{array}$ \\
\hline $\begin{array}{l}\text { Metz et al (19), } \\
\text { RCO }\end{array}$ & $\begin{array}{l}\text { Sample: Patients in ICU requiring MV for acute } \\
\text { respiratory failure }(\mathrm{n}=16) \\
\text { Intervention 1: Standard off-ventilator suction } \\
\text { Intervention 2: Suctioning through an adaptor } \\
\text { with intermittent ETT clamping } \\
\text { All patients received hyperoxygenation before } \\
\text { and hyperoxygenation and hyperinflation } \\
\text { postsuctioning }\end{array}$ & $\mathrm{PaO}_{2}$ & $\begin{array}{l}\text { No between-group comparisons } \\
\text { reported } \\
\text { Within group changes were significant } \\
(\mathrm{P}<0.05) \text { up to } 60 \text { min postsuctioning } \\
\text { with intervention } 1 \text { causing a decrease } \\
\text { in } \mathrm{PaO}_{2} \text { and intervention } 2 \text { causing an } \\
\text { increase in } \mathrm{PaO}_{2}\end{array}$ \\
\hline
\end{tabular}

ALI Acute lung injury; ASL Alternate side lying; CS Closed suctioning; ETT Endotracheal tube; ICU Intensive care unit; MV Mechanical ventilation; OS Open suctioning; $\mathrm{PaCO}_{2}$ Arterial pressure of carbon dioxide; $\mathrm{PaO}_{2}$ Arterial pressure of oxygen; PEEP Positive end-expiratory pressure; RCO Randomized crossover study; $R C T$ Randomized controlled trial; $\mathrm{SVO}_{2}$ Mixed venous oxygen saturation; VAP Ventilator-associated pneumonia; $V_{T}$ Tidal volume

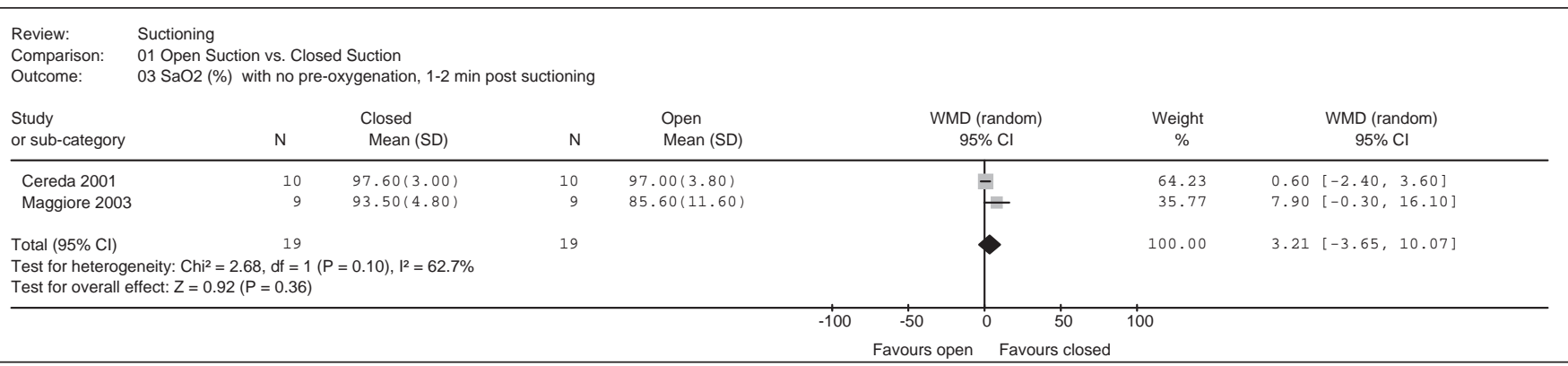

Figure 1) Meta-analysis for open suction versus closed suction on arterial oxygen saturation $\left(\mathrm{SaO}_{2}\right)$, \% , without preoxygenation. No significant difference between interventions. df Degrees of freedom; WMD Weighted mean difference

\section{OS versus CS systems}

OS refers to the suctioning technique in which patients are disconnected from the ventilator and a single use catheter is inserted into the ETT to suction secretions before the patient is reconnected. CS is the suctioning technique in which the suction catheter is enclosed in a plastic sleeve and can be inserted into the ETT without the need for disconnection from the ventilator. In the previous $\mathrm{CPG}$, there was insufficient evidence on which to base a recommendation regarding the effectiveness of CS or OS on oxygenation, secretion removal or frequency of colonization for pneumonia. No meta-analyses were conducted in the previous CPG. Our group located seven new RCTs and five new RCO studies (Table 2). There were enough new studies to conduct meta-analyses on the effectiveness of CS versus OS systems on $\mathrm{SaO}_{2}$ (without preoxygenation), end-expiratory lung volume (without preoxygenation) and VAP (incidence and incidence per 1000 patient days). Qualitative analyses on outcome measures were conducted in cases for which there was either large heterogeneity or too few studies to combine for meta-analysis.

Quantitative analyses: Two new RCO studies $(8,20)$ assessed changes in $\mathrm{SaO}_{2}$ in 19 subjects during OS and CS, both without preoxygenation. A meta-analysis (Figure 1) indicated that there was no difference between the two systems (weighted mean difference $[\mathrm{WMD}]=3.21 \% ; 95 \% \mathrm{CI}-3.65 \%$ to $10.07 \%)$. The same two studies assessed the effect of OS and 
TABLE 2

Summary of randomized studies on open (OS) and closed suctioning (CS)

\begin{tabular}{|c|c|c|c|}
\hline $\begin{array}{l}\text { Author (reference), } \\
\text { study design }\end{array}$ & Description of groups and interventions & Outcome measures & Summary of main results \\
\hline $\begin{array}{l}\text { Bourgault et al (7), } \\
\text { RCO }\end{array}$ & $\begin{array}{l}\text { Sample: Positive pressure MV patients, } \\
\text { PEEP } \leq 7.5 \mathrm{~cm} \mathrm{H}_{2} \mathrm{O}(\mathrm{n}=18) \\
\text { Intervention } 1 \text { : OS } \\
\text { Intervention } 2 \text { : } \mathrm{CS}, 2 \text { suction passes, } \\
15 \mathrm{~s} / \text { pass, } 30 \mathrm{~s} \text { on } \mathrm{MV} \text { between passes, } \\
100 \% \mathrm{O}_{2} \text { for } 1 \mathrm{~min} \text { ( } 20 \text { breaths) before } \\
\text { first pass, } 120 \mathrm{mmHg} \text { pressure }\end{array}$ & $\begin{array}{l}\mathrm{PaO}_{2} \\
\text { Heart rate variability } \\
\text { Baroreflex sensitivity }\end{array}$ & $\begin{array}{l}\text { No significant difference between } \\
\text { interventions for any outcome } \\
\text { measure }\end{array}$ \\
\hline $\begin{array}{l}\text { Maggiori et al (8), } \\
\text { RCO }\end{array}$ & $\begin{array}{l}\text { Sample: Patients in ICU with ARDS/ALI } \\
\text { requiring MV }(\mathrm{n}=18) \\
\text { Intervention 1: suction after disconnection from } \\
\text { ventilator (DISCONNECT) } \\
\text { Intervention 2: suction through swivel adaptor of } \\
\text { catheter mount (SWIVEL) } \\
\text { Intervention 3: CS } \\
\text { Intervention 4: suction during SWIVEL with PS } \\
\text { Intervention 5: CS with PS }\end{array}$ & $\begin{array}{l}\text { EELV } \\
\text { Alveolar recruitment } \\
\mathrm{SpO}_{2}\end{array}$ & $\begin{array}{l}\text { Greater loss of EELV after } \\
\text { DISCONNECT }(P<0.001) \\
\text { Alveolar recruitment decreased after } \\
\text { DISCONNECT and SWIVEL }(P<0.01) \\
\text { and increased after SWIVEL and CS } \\
\text { with PS }(P<0.01) \\
\text { Decrease in } \mathrm{SpO}_{2} \text { was greater after } \\
\text { DISCONNECT }(P<0.01)\end{array}$ \\
\hline $\begin{array}{l}\text { Cereda et al (20), } \\
\text { RCO }\end{array}$ & $\begin{array}{l}\text { Sample: Patients in ICU with ALI requiring MV. } \\
\text { PEEP } \geq 5 \mathrm{cmH}_{2} \mathrm{O} \text { (range } 5-15 \text { ), with VCV and } \\
\text { pharmaceutically paralyzed with hourly boluses } \\
(\mathrm{n}=10) \\
\text { Intervention 1: OS } \\
\text { Intervention 2, CS: Alternate randomized }\end{array}$ & $\begin{array}{l}\text { Lung volume } \\
\mathrm{SpO}_{2} \\
\text { Airway pressure } \\
\text { Arterial gases } \\
\text { Heart rate } \\
\text { Arterial pressure }\end{array}$ & $\begin{array}{l}\text { Greater loss of lung volume }(\mathrm{P}<0.010) \\
\text { and decrease in } \mathrm{SpO}_{2}(\mathrm{P}<0.05) \text { with } \\
\text { intervention } 1\end{array}$ \\
\hline
\end{tabular}

Combes et al (21), RCT suction (OS, CS and CS, OS) with $20 \mathrm{~min}$ recovery between suction manoeuvres

Sample: Neurosurgical patients requiring MV $(n=104)$

Group 1 OS $(n=54)$ : Suction passes in a single suctioning event used the same catheter following cleansing with sterile solution

Group $2(\mathrm{n}=50)$ : CS For both groups: clean gloves used, suctioned every $2 \mathrm{~h}$, if second suction required, catheter cleaned with sterile solution

Lorente et al (22), RCT

Sample: Patients in ICU requiring $>24 \mathrm{~h}$ continuous MV ( $n=443)$

Group 1 ( $n=233)$ : OS

Group 2 ( $n=210)$ : CS, both groups received identical strict protocols to minimize risk of VAP

Barrier measures for group 1 only

Lorente et al (23), Sample: Patients in ICU requiring MV $(n=457)$ RCT

Group 1 ( $n=236)$ : OS, aseptic technique, one catheter for each aspiration

Group 2 ( $n=221)$ : CS, changed catheter only when necessary (mechanical failure or soil ing), used universal precautions

Both groups received identical strict protocols to minimize risk of VAP. Barrier measures for group 1 only

Rabitsch et al (24), RCT

System: Patients in ICU requiring MV $\geq 3$ days $(n=24)$

Group $1(n=12)$ : OS, using a new catheter for each pass

Group 2 ( $n=12)$ : CS, catheter replaced every $24 \mathrm{~h}$

Topeli et al (25), RCT

Sample: Patients in MICU requiring MV $>24 \mathrm{~h}$ $(n=78)$

Group 1 ( $n=37)$ : OS performed through a T tube without removing patient from ventilator, using aseptic technique

Group 2 ( $n=41)$ : CS used repeatedly, changed when grossly contaminated or integrity of catheter was compromised

Incidence of VAP

LOS in ICU

Incidence of VAP

Microorganisms isolated in VAP

Duration of days on MV

Cost

Incidence of VAP

Incidence of VAP/1000 days of MV Cost

Bronchial contamination with gastric juices (cross-contamination) Incidence of VAP $\mathrm{SpO}_{2}$

Incidence of VAP

Mortality

LOS (in ICU)

Duration of MV

Colonization of MV circuit
Risk of VAP was 3.5 times higher in group 1 versus group $2(P=0.05)$
No significant difference for incidence of VAP, microorganisms isolated and days on MV

Group 2 had greater costs $(P<0.001)$

No significant difference in incidence of VAP, or incidence of VAP/1000 days of $\mathrm{MV}$

For $\mathrm{MV}<4$ days, cost for group 2 greater than for group $1(P<0.001)$. For MV $>4$ days, cost for group 2 less than for group $1(\mathrm{P}<0.001)$

Group 1 had more cross-contamination and incidence of VAP $(\mathrm{P}=0.037)$ Decrease in $\mathrm{SpO}_{2}$ was greater in group $1(\mathrm{P}<0.001)$

No significant cross-contamination in group 2

No significant difference in VAP, mortality, LOS (in ICU) or duration of MV

Colonization of MV circuit was greater in group $2(P<0.01)$

continued on next page 
TABLE 2 - CONTINUED

Summary of randomized studies on open (OS) and closed suctioning (CS)

\section{Author (reference),}

study design

Lasocki et al (27), $\mathrm{RCO}$

Lee et al (28), $\mathrm{RCO}$ RCT RCT
Description of groups and interventions

Sample: Patients in ICU with ALI requiring MV $(n=18)$

Part $1(n=9)$ : Preoxygenation, $100 \% \mathrm{O}_{2}$ for $15 \mathrm{~min}$

Intervention 1: OS, $-200 \mathrm{cmH}_{2} \mathrm{O}$ for $20 \mathrm{~s}$

Intervention 2: CS, catheter inserted in swivel adaptor, $-200 \mathrm{cmH}_{2} \mathrm{O}$ for $20 \mathrm{~s}$ followed by recruitment manoeuvre (20 breaths at $2 \times \mathrm{V}_{\mathrm{T}}$ ) Part $2(n=9)$

Intervention 1: CS at $-200 \mathrm{cmH}_{2} \mathrm{O}$

Intervention 2: $\mathrm{CS}$ at $-400 \mathrm{cmH}_{2} \mathrm{O}$

For both interventions, suction followed by recruitment manoeuvre (20 breaths at $2 \times V_{T}$ )

Sample: Patients in SICU requiring MV $(n=14)$

Intervention 1: OS

Intervention 2: CS

For both interventions: 60 s hyperoxygenation,

10 s suction, 30 s hyperoxygenation,

10 s suction, 30 s hyperoxgygenation

Darvas and Hawkins (29), Sample: Patients in ICU requiring MV ( $n=101)$

Group 1 ( $n=53)$ : CS (catheter replaced every $24 \mathrm{~h}$ )

Group 2 ( $\mathrm{n}=48$ ): CS (catheter replaced every $48 \mathrm{~h}$ )

'Standard suction procedure' with sterile saline rinse for $\mathrm{CS}$

System: Patients in ICU requiring MV for $>48 \mathrm{~h}$, $(n=73)$

Group $1(n=34)$ : CS (catheter replaced every $24 \mathrm{~h}$ )

Group 2 ( $n=39)$ : CS (catheter replaced every $48 \mathrm{~h}$ )

$\mathrm{CS}$ catheter tips were examined for colonization

at $24 \mathrm{~h}$ and $48 \mathrm{~h}$ postintubation

Sputum samples were taken at $24 \mathrm{~h}$ and $48 \mathrm{~h}$

Summary of main results

Outcome measure

$\mathrm{PaO}_{2}$

Wet aspirate mass

Part 1: Decrease in $\mathrm{PaO}_{2}$ was greate with intervention $1(P=0.015)$.

Wet aspirate mass greater with intervention 1 at suction pressure of $-200 \mathrm{cmH}_{2} \mathrm{O}(\mathrm{P}=0.03)$

Part 2: No significant differences in $\mathrm{PaO}_{2}$ between interventions. Increase in wet aspirate mass for

Heart rate

MAP

$\mathrm{SpO}_{2}$

ECG rhythm

Incidence of VAP

Duration of MV

LOS in ICU

Mortality

Colonization of sputum

Colonization of suction catheter tips LOS in ICU

Mortality intervention $2(\mathrm{P}=0.02)$.

Intervention 1 elicited higher heart rate and MAP $(P \leq 0.05)$ and lower $\mathrm{SpO}_{2}$ $(P \leq 0.01)$ during and after suctioning. Intervention 1 had a greater incidence of arrhythmias ( $\mathrm{P} \leq 0.05)$.

NOTE: Query clinical significance of changes

No significant difference between groups for any outcome measure.

No significant difference in number of colonized suction tips, or in number of sputum colonies at $48 \mathrm{~h}$

In colonized tips, greater number of colonies for group $2(\mathrm{P}<0.05)$

No significant difference between groups in LOS in ICU or mortality

ALI Acute lung injury; ARDS Acute respiratory distress syndrome; BP Blood pressure; CS Closed suctioning; ECG Electrocardiogram; EELV End-expiratory lung volume; ICU Intensive care unit; LOS Length of stay; MAP Mean arterial pressure; MICU Medical intensive care unit; MV Mechanical ventilation; OS Open suctioning; $\mathrm{PaO}_{2}$ Arterial pressure of oxygen; PEEP Positive end-expiratory pressure; PS Pressure support; RCO Randomized crossover study; RCT Randomized controlled trial; $\mathrm{SaO}_{2}$ Arterial oxygen saturation; SICU Surgical intensive care unit; $\mathrm{SpO}_{2}$ Oxygen saturation by pulse oximetry; VAP Ventilator-associated pneumonia; VCV Volume control ventilation; $V_{T}$ Tidal volume

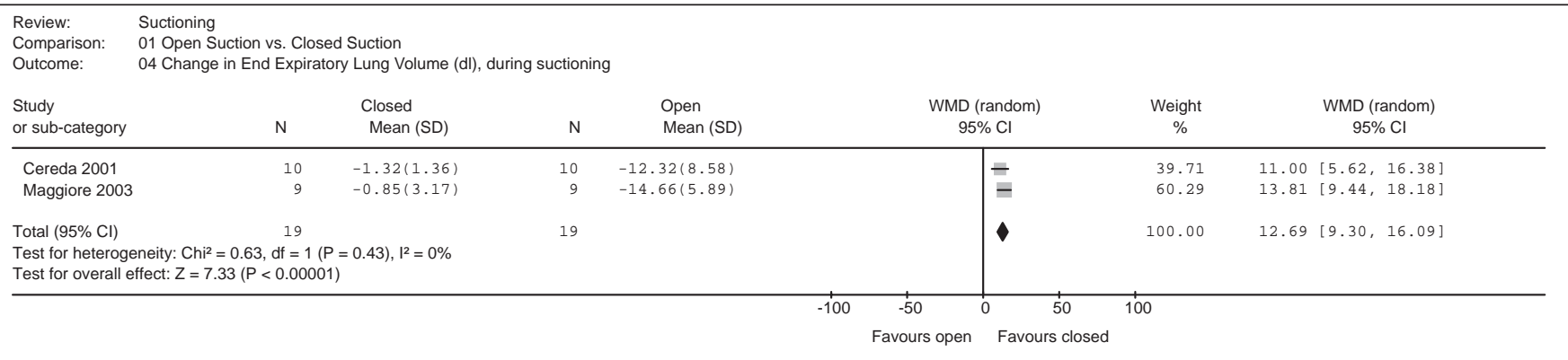

Figure 2) Meta-analysis for open suction versus closed suction on end-expiratory lung volume (EELV), without preoxygenation. Closed suction had significantly greater EELV. df Degrees of freedom; WMD Weighted mean difference

CS on end-expiratory lung volume. The result was significantly in favour of CS (WMD $=12.69 \mathrm{dL} ; 95 \% \mathrm{CI} 9.30 \mathrm{dL}$ to $16.09 \mathrm{dL}$ ) (Figure 2).

Five new RCTs (21-25) investigated the effect of CS and OS on the incidence of VAP (total $n=189$; CS $n=93$; OS $n=96$ ). There was no difference (Figure 3 ) between the two systems (pooled OR=0.96; 95\% CI 0.60 to 1.52). Combes et al (21) and Lorente et al $(22,23)$ investigated the incidence of VAP per 1000 patient days (total $n=86$; CS $n=39$; OS $n=47$ ). Meta-analysis indicated that there was no difference (Figure 3) between the two suctioning systems (pooled $\mathrm{OR}=0.82 ; 95 \% \mathrm{CI} 0.48$ to 1.39 ).

Summary: The new evidence indicates that CS systems preserve end-expiratory lung volumes. The new evidence also indicates that there is no difference between OS and CS systems with respect to oxygenation and incidence of VAP.

This summary is supported by the recently published Dutch Working Party on Infection Prevention suctioning policies for prevention of VAP (26). The Dutch Working Party recommended 


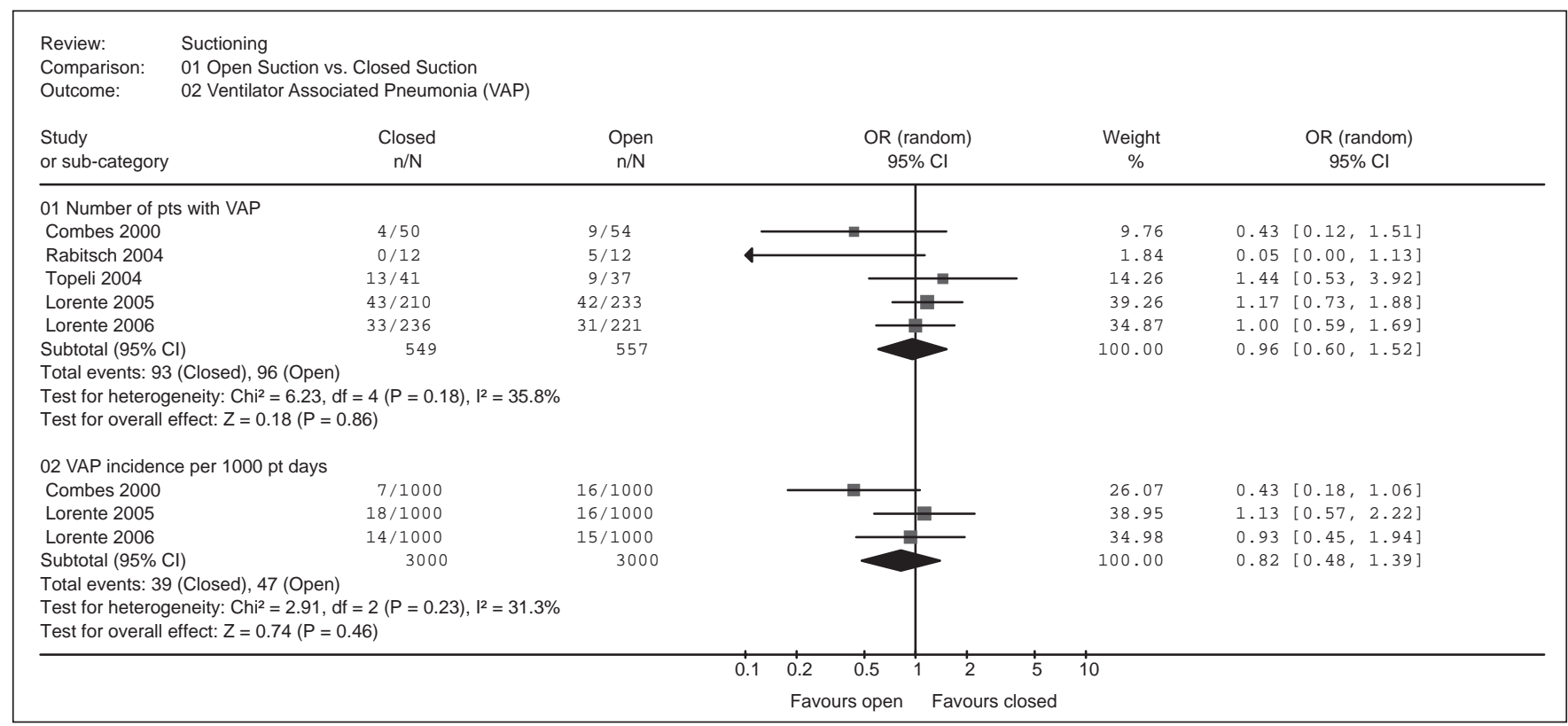

Figure 3) Meta-analyses for open suction versus closed suction on ventilator-associated pneumonia (VAP). Top analysis: number of patients with ventilator-assisted pneumonia (VAP). Bottom analysis: Incidence of VAP per 1000 patient days. No significant difference between interventions. If Degrees of freedom; N Number of patients in the group; $n$ Number of patients with VAP; pts Patients

no preferential use of either type of suctioning system, although qualified their recommendation with the caveat that the quality of the included studies was low.

Qualitative analyses: Two RCO studies (7,27) investigated changes in $\mathrm{PaO}_{2}$ immediately ( 1 min or less), and 3 min to $5 \mathrm{~min}$ after CS and OS; both methods were preceded by oxygenation. Bourgault et al (7) provided 1 min of $100 \% \mathrm{O}_{2}$ before suctioning. Lasocki et al (27) provided $100 \% \mathrm{O}_{2}$ for 15 min before, during and $15 \mathrm{~min}$ after suctioning, along with a 20 breath $\left(2 \times V_{\mathrm{T}}\right)$ recruitment manoeuvre immediately postsuction. Neither study showed a significant difference between CS and OS methods on immediate (1 min or less) or short-term (3 min to $5 \mathrm{~min}$ ) postsuctioning $\mathrm{PaO}_{2}$ levels.

Two RCTs $(22,23)$ investigated the cost of OS and CS systems. Lorente et al (22) reported a higher cost for CS (US $\$ 11.11 \pm 2.25 /$ patient/day versus US $\$ 2.50 \pm 1.12 /$ patient/day). A subsequent study (23) supported this result, but only in patients who were mechanically ventilated for less than four days. When patients were ventilated for longer periods, CS systems were less expensive ( $€ 1.6 \pm 2.8 /$ patient/day versus $€ 2.5 \pm 0.5 /$ patient/day).

Two new RCTs $(21,25)$ compared OS and CS systems with respect to length of stay (LOS) in the ICU. Neither study reported a significant difference. Topeli et al (25) also found no difference between suctioning systems on mortality.

Two new RCTs $(22,25)$ compared OS and CS systems on the duration of MV in ICU patients. Neither of the studies reported a significant difference between the two procedures.

Only two new RCO studies $(20,28)$ investigated the effect of CS and OS systems on HR and blood pressure (BP). Cereda et al (20) reported no differences between systems. Lee et al (28) found higher HR and BP values following OS; however, the clinical significance of the magnitude of the differences $(3 \%$ to $6 \%$ ) between the suctioning systems is difficult to assess.

Summary: The new evidence suggests that there is no difference between CS and OS for oxygenation, mortality, LOS in ICU or duration of MV. CS systems are more expensive than OS systems, although the difference may depend on the duration of MV.

\section{Frequency of changing CS systems}

Two new studies $(29,30)$ investigated the effect of changing CS catheters at $24 \mathrm{~h}$ or $48 \mathrm{~h}$ intervals (Table 2). Darvas and Hawkins (29) found no differences in the incidence of VAP, duration of MV or LOS in ICU, or mortality. Quirke (30) also found no differences in LOS in ICU or mortality. There were also no differences in the overall number of colonized suction tips or the number of sputum colonies; however, the study did report a greater number of colonies in colonized tips in the group whose catheters were changed every $48 \mathrm{~h}$.

Summary: The new evidence suggests that there is no difference between $24 \mathrm{~h}$ and $48 \mathrm{~h}$ changes of CS systems with respect to the incidence of VAP, mortality, LOS in ICU, duration of MV or colonization of catheter tips.

The Dutch Working Group on Infection Prevention (26) also investigated the frequency of changing CS systems and recommended a change at $48 \mathrm{~h}$ unless there was mechanical failure or soiling of the suction system.

\section{Subglottic suctioning}

Subglottic suction refers to the technique in which an ETT is modified to allow suction above the cuff. The suction is used to remove secretions that pool above the cuff, which prevents aspiration of these secretions into the lung. The 2001 CPG (4) found some evidence to support the use of such modified ETTs, with capabilities for continuous or intermittent subglottic suctioning to prevent subglottic aspiration. Two new RCTs $(31,32)$ that addressed subglottic aspiration of secretions in subjects expected to receive more than $72 \mathrm{~h}$ of MV were found (Table 3 ). Smulders et al (31) investigated the effect of subglottic secretion drainage on the incidence of VAP in ICU patients. Patients received standard ETT suction $(n=75)$ or intermittent subglottic 
TABLE 3

Summary of randomized studies on subglottic suctioning

\begin{tabular}{|c|c|c|c|}
\hline $\begin{array}{l}\text { Author (reference), } \\
\text { study design }\end{array}$ & Description of groups and interventions & Outcome measures & Summary of main results \\
\hline $\begin{array}{l}\text { Smulders et al (31), } \\
\text { RCT }\end{array}$ & $\begin{array}{l}\text { Sample: Patients in ICU requiring MV }(n=150) \\
\text { Group } 1(n=75) \text { : Suction through conventional ETT } \\
\text { Group } 2(n=75) \text { : ETT with intermittent } \\
\text { subglottic suction }\end{array}$ & $\begin{array}{l}\text { Incidence of VAP } \\
\text { Duration of MV } \\
\text { LOS (in ICU) } \\
\text { LOS (in hospital) } \\
\text { Mortality in ICU }\end{array}$ & $\begin{array}{l}\text { Lower incidence of VAP in group } 2 \\
\quad(P=0.014) \\
\text { No significant difference between } \\
\text { groups for other outcome measures }\end{array}$ \\
\hline $\begin{array}{l}\text { Girou et al (32), } \\
\text { RCT }\end{array}$ & $\begin{array}{l}\text { Sample: Patients in MICU requiring MV }(n=18) \\
\text { Group } 1(n=10) \text { : Suctioning with standard ETT } \\
\text { and placed supine } \\
\text { Group } 2(n=8): \text { Subglottic suctioning through } \\
\text { ETT and placed in a semirecumbent }\left(30^{\circ}\right) \\
\text { position }\end{array}$ & $\begin{array}{l}\text { Bacterial counts } \\
\text { Time course of colonization }\end{array}$ & $\begin{array}{l}\text { No significant difference in bacterial } \\
\text { counts or time course between } \\
\text { groups. }\end{array}$ \\
\hline
\end{tabular}

ETT Endotracheal tube; ICU Intensive care unit; LOS Length of stay; MICU Medical intensive care unit; MV Mechanical ventilation; RCT Randomized controlled trial

suction $(n=75)$. There was a significantly lower incidence of VAP in the group receiving subglottic suction (4\% versus 16\%). Girou et al (32) examined the effect of positioning in medical ICU patients. Patients received standard suction in supine $(n=8)$, or continuous subglottic suction in a semirecumbent (30 degrees) position $(n=10)$. There was no difference in the incidence of tracheal colonization or the time course of colonization between the two methods. It is difficult to directly compare these two studies because the methods and outcome measures were not equivalent. Girou et al (32) investigated both the effect of positioning and subglottic suction, and studied bacterial counts and time course of tracheal colonization in very small sample groups. Using much larger sample sizes, Smulders et al (31) studied the incidence of VAP, duration of MV, LOS in ICU and in hospital, and mortality in ICU, with positioning held constant.

Kollef et al (33) investigated whether continuous aspiration of subglottic secretions (CASS) decreased the incidence of VAP in patients receiving MV (mean 1.5 days) following cardiac bypass surgery. Patients received either CASS through a specially designed ETT $(n=160)$ or routine postoperative care without CASS $(n=183)$. Risk factors for VAP were equal between groups. The relative risk for VAP suggested no difference between the two systems $(R R=0.61 ; 96 \% \mathrm{CI} 0.27$ to 1.40 ; $\mathrm{P}=0.238$ ). Episodes of VAP occurred significantly later among patients receiving CASS, thus suggesting a possible delaying role for this procedure. The inferences that can be made from these results may be limited because subjects were randomly assigned according to their year of birth.

One case report (34) described a patient who had a fatal tracheal-innominate artery fistula formation associated with an ETT tip. The authors believed that the higher rigidity of the ETT with a subglottic suction port, the extended duration of intubation and the complexity of the patient's airway management problems (second- and third-degree burns to the face and neck, ETT sutured in place) may have contributed. Under normal circumstances, ETTs with subglottic suction ports do not impose greater risk.

The optimal pressure used for subglottic drainage is not clear. A laboratory model study (35) found that a pressure of $30 \mathrm{mmHg}$ was more effective than $10 \mathrm{mmHg}, 40 \mathrm{mmHg}$ or $50 \mathrm{mmHg}$ in removing all types of secretions; however, the authors did not examine the effect on mucosal damage.
Summary: The new evidence continues to support the use of subglottic suctioning for the prevention of pneumonia in patients expected to require greater than $72 \mathrm{~h}$ of MV.

\section{Minimally invasive suctioning}

Minimally invasive suction is a technique designed to have less impact on the patient. No saline is instilled, no hyperinflation or hyperoxygenation is applied, and the suction catheter (open) does not pass beyond the tip of the ETT. Two new RCTs $(36,37)$ investigated minimally invasive suction (Table 4). Leur et al (36) compared standard OS (49 cm catheter; $n=197$ ) with on-demand minimally invasive OS $(29 \mathrm{~cm}$ catheter; $n=186$ ). There were no differences between groups for duration of $\mathrm{MV}$, incidence of pulmonary infection, mortality or LOS in the ICU. Patients who received minimally invasive OS reported fewer adverse effects (decreased $\mathrm{SaO}_{2}$ and arrhythmias, increased BP and pulse pressure, and hemoptysis). However, this study was flawed because 163 members of the minimally invasive suction group received standard OS (total of $10 \%$ of all suction interventions) when nurses believed that the minimally invasive treatment was not working well. Treatment was also withheld from 63 standard OS patients because nurses believed treatment was not indicated.

Leur et al (37) assessed the recollection of suctioning and discomfort with suctioning in a subset of these patients, and found a lower prevalence of recollection in the group receiving minimally invasive suctioning. However, among subjects who recalled the suctioning experience (OS $n=46$; minimally invasive OS $n=19$ ), there was no difference in the reported level of discomfort between the two suctioning techniques. The issue of minimally invasive suctioning has emerged only since the most recent CPG (4), and these two studies $(36,37)$ are too weak to enable any conclusions.

\section{Saline instillation}

Saline instillation is the practice of instilling aliquots of saline (generally $2.5 \mathrm{~mL}$ to $5 \mathrm{~mL}$ ) into the ETT just before inserting the suction catheter. The controversy over the use of saline has continued since the completion of the 2001 CPG (4), which reported insufficient evidence to make a recommendation. We found one new RCT and two new RCO studies in mechanically ventilated patients (Table 5). Outcome measures included saturation and dyspnea (by visual analogue scale). 
TABLE 4

Summary of randomized studies on minimally invasive suctioning

\begin{tabular}{|c|c|c|c|}
\hline $\begin{array}{l}\text { Author (reference), } \\
\text { study design }\end{array}$ & Description of groups and interventions & Outcome measures & Summary of main results \\
\hline $\begin{array}{l}\text { Leur et al (36), } \\
\text { RCT }\end{array}$ & $\begin{array}{l}\text { Sample: Patients in a cardiothoracic and general } \\
\text { surgery ICU requiring MV }(n=383) \\
\text { Group } 1(n=197) \text { : OS using a } 49 \mathrm{~cm} \text { suction catheter } \\
\text { Group } 2(n=186) \text { : On-demand minimally invasive OS } \\
\text { using a } 29 \mathrm{~cm} \text { suction catheter }\end{array}$ & $\begin{array}{l}\text { Duration of mechanical ventilation } \\
\text { LOS (in ICU) } \\
\text { LOS (in hospital) } \\
\text { Incidence of pulmonary infection } \\
\text { Mortality } \\
\text { Adverse events }\end{array}$ & $\begin{array}{l}\text { No significant difference between groups in } \\
\text { duration of } \mathrm{MV} \text {, incidence of pulmonary } \\
\text { infection, mortality, LOS } \\
\text { Fewer adverse events in group } 2 \\
\text { (decreased } \mathrm{SaO}_{2} \text { and arrhythmias, } \\
\text { increased } \mathrm{SBP} \text {, pulse pressure and } \\
\text { hemoptysis) }(\mathrm{P}<0.01)\end{array}$ \\
\hline $\begin{array}{l}\text { Leur et al (37), } \\
\text { RCT }\end{array}$ & $\begin{array}{l}\text { Sample: Patients in a cardiothoracic and } \\
\text { general surgery ICU requiring MV }(n=208) \\
\text { Group } 1(n=113) \text { : OS using a } 49 \mathrm{~cm} \text { suction catheter } \\
\text { Group } 2(n=95) \text { : On-demand minimally invasive OS } \\
\text { using a } 29 \mathrm{~cm} \text { suction catheter }\end{array}$ & $\begin{array}{l}\text { Recollection of suctioning } \\
\text { Discomfort with suctioning (VAS) }\end{array}$ & $\begin{array}{l}\text { Lower prevalence of recollection in } \\
\text { group } 2(P=0.001) \\
\text { Of those who recalled the suctioning } \\
\text { experience (group } 1 \text { [ } n=46] \text {, group } 2 \\
\text { [n=19]), there was no significant } \\
\text { difference in reported level of } \\
\text { discomfort between groups }\end{array}$ \\
\hline
\end{tabular}

ETT Endotracheal tube; ICU Intensive care unit; MV Mechanical ventilation; OS Open suction; RCT Randomized controlled trial; SaO ${ }_{2}$ Arterial oxygen saturation; SBP Systolic blood pressure; VAS Visual analogue scale

TABLE 5

Summary of randomized studies on the use of saline

\begin{tabular}{|c|c|c|c|}
\hline $\begin{array}{l}\text { Author (reference), } \\
\text { study design }\end{array}$ & Description of groups and interventions & Outcome measures & Summary of main results \\
\hline $\begin{array}{l}\text { Ji et al (38), } \\
\text { RCO }\end{array}$ & $\begin{array}{l}\text { Sample: Neurosurgical patients with pneumonia } \\
\text { requiring } \mathrm{MV}(\mathrm{n}=21,16 \text { completed study) } \\
\text { Intervention 1: OS } \\
\text { Intervention 2: OS with } 2 \mathrm{~mL} \text { of saline } \\
\text { Intervention 3: OS with } 5 \mathrm{~mL} \text { of saline }\end{array}$ & $\mathrm{SpO}_{2}$ & $\begin{array}{l}\mathrm{SpO}_{2} \text { returned to baseline immediately for intervention } 1 \text {, } \\
\text { at } 45 \mathrm{~s} \text { for intervention } 2 \text { and did not return to baseline } \\
\text { by } 5 \text { min for intervention } 3(\mathrm{P}=0.003) \\
\text { NOTE: the } \mathrm{SpO}_{2} \text { decreases with saline were } \\
\text { not clinically significant at all times ( } 1 \% \text { to } 2 \%)\end{array}$ \\
\hline $\begin{array}{l}\text { Ackerman and Mick (39), } \\
\text { RCT }\end{array}$ & $\begin{array}{l}\text { Sample: Patients in ICU with pulmonary } \\
\text { infections requiring MV }(n=29) \\
\text { Group } 1(n=15): C S \\
\text { Group } 2(n=14): C S+5 m L \text { bolus of saline }\end{array}$ & $\begin{array}{l}\mathrm{SaO}_{2} \\
\text { Heart rate } \\
\text { Blood pressure }\end{array}$ & $\begin{array}{l}\text { Differences }(\mathrm{P}<0.05) \text { were found only in } \mathrm{SaO}_{2} \text { at } 4 \mathrm{~min} \text {, } \\
5 \mathrm{~min} \text { and } 10 \text { min postsuction for group } 2 \\
\text { NOTE: It is unlikely that these represent clinically } \\
\text { significant changes (decreases of } 1 \% \text { to } 2 \% \text { ) }\end{array}$ \\
\hline $\begin{array}{l}\text { O'Neal et al (40), } \\
\text { RCO }\end{array}$ & $\begin{array}{l}\text { Sample: Patients in ICU requiring MV ( } \mathrm{n}=20 \text {, } \\
17 \text { completed study) } \\
\text { Intervention 1: CS } \\
\text { Intervention 2: CS with } 5 \mathrm{~mL} \text { of saline }\end{array}$ & VAS for dyspnea & $\begin{array}{l}\text { No significant difference between interventions for } \\
\text { dyspnea }\end{array}$ \\
\hline
\end{tabular}

CS Closed suctioning; ICU Intensive care unit; MV Mechanical ventilation; OS Open suctioning; RCO Randomized crossover study; RCT Randomized controlled trial; $\mathrm{SaO}_{2}$ Arterial oxygen saturation; $\mathrm{SpO}_{2}$ Oxygen saturation by pulse oximetry; VAS Visual analogue scale

Ji et al (38) demonstrated that the $\mathrm{SpO}_{2}$ took longer to return to baseline following $O S$ with increasing amounts of saline $(0 \mathrm{~mL}, 2 \mathrm{~mL}, 5 \mathrm{~mL})$. However, it is unlikely that these differences would be clinically significant because the changes were very small (less than $2 \%$ difference in $\mathrm{SpO}_{2}$ ). Similarly, in a small RCT, Ackerman and Mick (39) found that $\mathrm{SaO}_{2}$ decreased to a greater extent with the use of saline at $4 \mathrm{~min}$, $5 \mathrm{~min}$ and $10 \mathrm{~min}$ postsuctioning. Again, the changes were very small and likely clinically insignificant. In a lower-level study, O'Neal et al (40) reported no difference in the level of dyspnea with saline instillation in mechanically ventilated patients. In a subanalysis, the authors found that older patients (older than 60 years of age) reported higher levels of dyspnea with saline. However, these results must be interpreted with caution due to the very small sample size $(n=5)$.

The distribution of saline in patients receiving MV was examined in a small crossover pilot study (41). In the supine position, greater amounts of instilled saline reached the posterior portion of the right lower lobe compared with the left. Klockare et al (41) also reported a more uniform distribution of saline between and within the lungs with nebulization versus instillation.
Summary: The new evidence suggests that the use of saline with suctioning may cause a decrease in oxygen saturation; however, this change may not be clinically significant. There is also some suggestion that it may be possible to manipulate the distribution of saline in the lung by the mode of delivery.

\section{Medications administered during suctioning}

The 2001 CPG (4) made recommendations regarding the use of medications for the prevention of increased intracranial pressure or cerebral perfusion pressure, and minimizing or decreasing bradycardia during suctioning. We found two new RCTs and one RCO that examined a variety of medications to assist in secretion clearance, suppressing cough and preventing deleterious changes in HR and mean arterial pressure (MAP) (Table 6).

Leone et al (42) studied 81 patients undergoing maxillo-facial surgery who received propofol (target concentration $3.5 \mu \mathrm{g} / \mathrm{mL}$ ) as well as three randomly assigned target concentrations of remifentanil. Patients who were given the highest concentration of remifentanil $(15 \mathrm{ng} / \mathrm{mL})$ had less coughing with suctioning than subjects receiving $5 \mathrm{ng} / \mathrm{mL}$ or $10 \mathrm{ng} / \mathrm{mL}$. MAP (74 $\mathrm{mmHg}$ versus $68 \mathrm{mmHg}$ versus $62 \mathrm{mmHg}$ for the three 
TABLE 6

Summary of randomized studies on the use of medications administered during suctioning

\begin{tabular}{|c|c|c|c|}
\hline $\begin{array}{l}\text { Author (reference), } \\
\text { study design }\end{array}$ & Description of groups and interventions & Outcome measures & Summary of main results \\
\hline $\begin{array}{l}\text { Leone et al (42), } \\
\text { RCT }\end{array}$ & $\begin{array}{l}\text { Sample: Patients in ICU requiring MV } \\
\text { undergoing maxillofacial surgery, } \\
\text { receiving propofol ( } \mathrm{n}=81) \text { ( } 1 \text { dropout) } \\
\text { Group } 1(\mathrm{n}=27) \text { : OS with remifentanil } \\
\text { at } 5 \mathrm{ng} / \mathrm{mL} \\
\text { Group } 2(\mathrm{n}=27) \text { : OS with remifentanil } \\
\text { at } 10 \mathrm{ng} / \mathrm{mL} \\
\text { Group } 3(\mathrm{n}=26) \text { : OS with remifentanil } \\
\text { at } 15 \mathrm{ng} / \mathrm{mL}\end{array}$ & $\begin{array}{l}\text { Cough (absent/present) } \\
\text { Heart rate } \\
\text { Mean arterial pressure }\end{array}$ & $\begin{array}{l}\text { Group } 3 \text { had decreased cough response }(P=0.007) \text {, } \\
\text { mean arterial pressure }(P<0.05) \text { and heart rate } \\
(P=0.005)\end{array}$ \\
\hline $\begin{array}{l}\text { Frass et al (46), } \\
\text { RCT }\end{array}$ & $\begin{array}{l}\text { Sample: Intubated patients with COPD } \\
\text { on CPAP, and extubation impossible } \\
\text { due to profuse, tenacious, stringy sputum } \\
\text { ( } n=55,5 \text { dropouts) } \\
\text { Group } 1 \text { ( } n=25) \text { : OS with potassium } \\
\text { dichromate globules } \\
\text { Group } 2 \text { ( } n=25) \text { : OS with placebo globules }\end{array}$ & $\begin{array}{c}\text { Tracheal secretions graded } \\
\text { by volume and viscosity }\end{array}$ & $\begin{array}{l}\text { By day } 2 \text {, decreased secretions in group } 1(P<0.0001) \\
\text { Shorter time to extubation }(P<0.0001) \text { and } \\
\text { LOS in group } 1(P<0.0001)\end{array}$ \\
\hline
\end{tabular}

COPD Chronic obstructive pulmonary disease; CPAP Continuous positive airway pressure; MV Mechanical ventilation; LOS Length of stay; OS Open suctioning; RCT Randomized controlled trial

concentrations, respectively; $\mathrm{P}=0.05$ ) and $\mathrm{HR}$ (66 beats $/ \mathrm{min}$ versus 61 beats $/ \mathrm{min}$ versus 55 beats $/ \mathrm{min}$, respectively; $\mathrm{P}=0.005$ ) also decreased to a greater degree with the $15 \mathrm{ng} / \mathrm{mL}$ concentration. Furthermore, in a lower-level design, Leone et al (43) demonstrated blunting of the cough reflex and changes in HR and MAP, using a continuous infusion of remifentanil in ventilated patients with severe closed head injury. HR decreased with all doses and MAP decreased significantly with the higher dose. Intracranial pressure increased in all three groups.

Studies have shown that pain stimulation results in an increase in the bispectral index (BIS) of an electroencephalograph if the level of analgesia is weak. In a small case series (44), the effect on BIS during suctioning of an intravenous bolus of alfentanil $(14 \mu \mathrm{g} / \mathrm{kg} / \mathrm{h})$ in addition to a consistent sedation protocol (midazolam $0.1 \mathrm{mg} / \mathrm{kg} / \mathrm{hr}$ and fentanyl at $4 \mu \mathrm{g} / \mathrm{kg}$ ), found that BIS values were significantly lower during the alfentanil period compared with the control period. Leone et al (43) reported that BIS increased significantly when higher doses of remifentanil were used alone without sedation. It should be noted, however, that a recent large RCT (45) failed to support routine BIS monitoring as part of standard practice to reduce anesthesia awareness; consequently, the value of BIS to assess responses to suction is unclear.

Frass et al (46) showed that compared with placebo, twice daily administration of the homeopathic mucolytic potassium dichromate (five spherical saccharose globules impregnated with a 30:1 dilution of potassium dichromate), reduced secretions, facilitated earlier extubation and decreased ICU LOS in patients with COPD who had failed extubation due to profuse, tenacious, stringy secretions.

Summary: The new evidence suggests that while remifentanil may blunt the cough reflex, it may also be associated with a decrease in HR and MAP. Potassium dichromate may help facilitate weaning in COPD patients with profuse, tenacious, stringy secretions.

\section{Infection control issues}

The 2001 CPG (4) identified only one study that examined whether suctioning technique should be clean or sterile; there was insufficient evidence to make a recommendation. Since that time, there have been two small case series $(47,48)$ (both $\mathrm{n}=20$ ) investigating the contamination of oral suction devices. One study (47) examined the contamination of endotracheal suctioning equipment, the other (48) was a case series that examined droplet spread with suctioning. Contamination of the oral suction device was common in both studies, yielding positive cultures in $94 \%$ and $80 \%$ of the devices, respectively. Both studies also reported a concern with the storage of suctioning equipment. Oral suction devices were found in beds, on medical equipment and even on the floor. Furthermore, Sole et al (48) found slightly lower contamination rates on the proximal end of the suction tubing (83\%) and connection port of the inline suction catheter $(61 \%) . \mathrm{Ng}$ et al (49) reported that visible droplets were scattered over a distance of $60 \pm 39 \mathrm{~cm}$ from the ETT and $30 \%$ of the bacteria were similar to those found in the trachea of OS patients.

Summary: Bedside storage of oral suctioning devices in a clean holder or other set up should be considered. Health care professionals must be cognizant of regional guidelines and standards for high-risk respiratory procedures in outbreak and nonoutbreak situations. This will generally include the use of personal protective equipment such as N95 masks for suctioning (eg, Ontario Ministry of Health Standards for All Health Care Facilities and Settings For High Risk Respiratory Procedures Under NonOutbreak Conditions, April 15, 2004) (50).

\section{Miscellaneous issues}

Frengley et al (51) studied airway pressures during CS suctioning in 16 patients using three different ventilator modes (pressure control, volume control and continuous positive airway pressure/pressure support) (Table 7). End-expiratory pressure increased to a greater extent with the insertion of the catheter, and subatmospheric airway pressures were detected during suctioning with volume control ventilation. These results were supported by a bench study (52).

Two new papers have studied the size of suction systems. In a very small RCO study, Vandenberg et al (53) demonstrated that a larger oral suction tip and tubing removed thicker substances from 
TABLE 7

Miscellaneous studies

\begin{tabular}{|c|c|c|c|}
\hline $\begin{array}{l}\text { Author (reference), } \\
\text { study design }\end{array}$ & Description of groups and interventions & Outcome measures & Summary of main results \\
\hline $\begin{array}{l}\text { Frengley et al (51), } \\
\text { RCO }\end{array}$ & $\begin{array}{l}\text { Sample: Patients in ICU requiring MV following } \\
\text { cardiac surgery ( } \mathrm{n}=16) \\
\text { Intervention 1: Pressure control mode } \\
\text { Intervention 2: Volume control mode } \\
\text { Intervention 3: CPAP-PSV proximal } \\
\text { ( } 2 \mathrm{~cm} \text { from tip of ETT) and distal } \\
\text { (10 cm to } 12 \mathrm{~cm} \text { from tip of ETT) airway } \\
\text { pressures measured during CS }\end{array}$ & $\begin{array}{l}\text { Airway pressure } \\
\text { End-expiratory pressure }\end{array}$ & $\begin{array}{l}\text { On insertion of catheter, end-expiratory } \\
\text { pressure increased in both interventions } 1 \\
\text { and } 2(P<0.001) \text {, with intervention } 2 \text { greater } \\
\text { than intervention } 1(P=0.018) \\
\text { Decrease in airway pressure for intervention } 2 \\
\text { was less than for interventions } 1 \text { or } 3 \\
(P<0.001)\end{array}$ \\
\hline $\begin{array}{l}\text { Vandenberg et al (53), } \\
\text { RCO }\end{array}$ & $\begin{array}{l}\text { Sample: One investigator (six trials for each } \\
\text { condition), } \mathrm{n}=1 \\
\text { Intervention 1: Yankauer with } 0.25 \text { in tubing } \\
\text { Intervention 2: } 0.25 \text { inch suction tip with } 0.25 \text { in tubing } \\
\text { Intervention 3: } 5 / 8 \text { inch suction tip with } 0.75 \text { in tubing } \\
\text { Viscosity levels: } 1 \text {. Water; } 2 \text {. Activated } \\
\text { charcoal; } 3 \text {. Vegetable soup } \\
\text { Suction pressure was }-500 \mathrm{mmHg}\end{array}$ & $\begin{array}{l}\text { Mean oropharyngeal } \\
\text { evacuation time }\end{array}$ & $\begin{array}{l}\text { Intervention } 3 \text { system was faster than other } \\
\text { systems for charcoal }(P<0.001) \\
\text { Intervention } 3 \text { system was faster than } \\
\text { intervention } 1(P<0.004) \text { and intervention } 2 \\
(P<0.002) \text { for vegetable soup }\end{array}$ \\
\hline
\end{tabular}

CPAP-PSV Continuous positive airway pressure - pressure support ventilation; CS Closed suctioning; ETT endotracheal tube; ICU intensive care unity; MV mechanical ventilation; RCO Randomized crossover study

the oropharynx more quickly (Table 7). In a bench study, Stenqvist et al (52) found that a larger catheter (14 Fr versus $12 \mathrm{Fr}$ ) inserted into a smaller endotracheal tube ( $7 \mathrm{~mm}$ versus $8 \mathrm{~mm}$ ) generated a much lower subatmospheric pressure (OS system).

Finally, the question of continuous versus intermittent suctioning has also been investigated. Stenqvist et al (52) evaluated the effect of suctioning on 'alveolar' pressure using a lung model with 12 Fr and 14 Fr suction catheters. They demonstrated that suction flow was very high for $2 \mathrm{~s}$ to $4 \mathrm{~s}$ when initial suctioning was applied. Thus, it appears that intermittent suctioning may result in higher suction flows each time suctioning is initiated, compared with continuous suctioning.

Summary: The best available new evidence suggests that health care providers should use caution with CS during volume-controlled ventilation. Catheter sizes should be matched appropriately with ETT sizes, and continuous suction may prevent the very high initial flows generated with intermittent suctioning.

\section{CONCLUSION}

Suctioning is a technique used by many members of the health care team along the continuum from critical care to patients at home. Controversy remains over the optimum technique for this procedure, which is not without its risks to patients. The present systematic review has provided an update

\section{REFERENCES}

1. AARC Clinical Practice Guideline. Endotracheal suctioning of mechanically ventilated adults and children with artificial airways. Respir Care 1993;38:500-4.

2. AARC Clinical Practice Guideline. Suctioning of the patient in the home. Respir Care 1999;44:99-104.

3. Thompson L. Suctioning adults with an artificial airway. The Joanna Briggs Institute for Evidence Based Nursing and Midwifery. Systematic Review 9, $2000<$ www.joannabriggs.edu.au/pubs/ systematic_reviews.php> (Version current at May 19, 2009).

4. Brooks D, Anderson CM, Carter MA, et al. Clinical practice guidelines for suctioning the airway of the intubated and nonintubated patient. Can Respir J 2001;8:163-81.

5. Anderson CM, Overend TJ, Lucy SD. Changing practice through a systematic review: Reflections from experience. Physiother Can 2002;54:186-98, 205. of the evidence related to suctioning adult patients since the publication of the most current CPG (4). We have been able to provide a quantitative summary of the evidence on $O S$ versus CS systems for specific outcome measures including VAP, endexpiratory lung volume and $\mathrm{SaO}_{2}$. We have also presented a qualitative summary of the new evidence relating to many other areas of suctioning practice. The information we have provided in our review is important to guide the health care team in the provision of best practice for our patients.

It is necessary to recognize, however, that sample sizes in most of the new literature are small, and there continues to be gaps with respect to indications for suctioning, optimal suction pressures, clean versus sterile technique and the duration of the suction pass. In addition, there is very limited information regarding suctioning technique in nonintubated patients. Thus, there remains a need for further work in many areas related to suctioning practice.

ACKNOWLEDGEMENTS: Funding for this study was provided by the Physiotherapy Foundation of Canada.

This work originated from the School of Physical Therapy, University of Western Ontario, and the London Health Sciences Centre, London, Ontario.

6. Nonoyama ML, Brooks D, Lacasse Y, Goldstein RS, Guyatt GH. Oxygen therapy for exercise training or rehabilitation in chronic obstructive pulmonary disease (Protocol) The Cochrane Database of Syst Rev CD005372.

7. Bourgault AM, Brown CA, Hains SM, Parlow JL. Effects of endotracheal tube suctioning on arterial oxygen tension and heart rate variability. Biol Res Nurs 2006;7:268-78.

8. Maggiore SM, Lellouche F, Pigeot J, et al. Prevention of endotracheal suctioning-induced alveolar derecruitment in acute lung injury. Am J Respir Crit Care Med 2003;167:1215-24.

9. Demir F, Dramali A. Requirement for $100 \%$ oxygen before and after closed suction. J Adv Nurs 2005;51:245-51.

10. Akgul S, Akyolcu N. Effects of normal saline on endotracheal suctioning. J Clin Nurs 2002;11:826-30.

11. Jadad AR, Moore RA, Carroll D, et al. Assessing the quality of 
randomized controlled trials: Is blinding necessary? Control Clin Trials 1996;17:1-12.

12. Maher CG, Sherrington C, Herbert RD, Mosely AM, Elkins M. Reliability of the PEDro scale for rating quality of randomized controlled trials. Phys Ther 2003;83:713-21.

13. Cohen J. A coefficient of agreement for nominal scales. Educ Psychol Meas 1960;20:37-46.

14. Uebersax, J. Calculating Kappa with SAS. <http://ourworld. compuserve.com/homepages/jsuebersax/saskappa.htm $>$ (Version current at May 7, 2007).

15. Guglielminotti J, Alzieu M, Maury E, Guidet B, Offenstadt G. Bedside detection of retained tracheobronchial secretions in patients receiving mechanical ventilation: Is it time for tracheal suctioning? Chest 2000;118:1095-9.

16. Barker M, Adams S. An evaluation of a single chest physiotherapy treatment on mechanically ventilated patients with acute lung injury. Physiother Res Inter 2002;7:157-69.

17. Choi JS, Jones AY. Effects of manual hyperinflation and suctioning on respiratory mechanics in mechanically ventilated patients with ventilator-associated pneumonia. Aust J Physiother 2005;51:25-30.

18. Berney S, Denehy L. A comparison of the effects of manual and ventilator hyperinflation on static lung compliance and sputum production in intubated and ventilated intensive care patients. Physiother Res Inter 2002;7:100-8.

19. Metz C, Bein T, Sembach M, Taeger K. Maintaining positive airway pressure combined with final hyperinflation improves arterial oxygenation after tracheal suctioning in patients with acute respiratory failure. Clin Intensive Care 1996;7:131-7.

20. Cereda M, Villa F, Colombo E, Greco G, Nacoti M, Pesenti A. Closed system endotracheal suctioning maintains lung volume during volume-controlled mechanical ventilation. Intensive Care Med 2001;27:648-54

21. Combes P, Fauvage B, Oleyer C. Nosocomial pneumonia in mechanically ventilated patients, a prospective randomized evaluation of the Stericath closed suctioning system. Intensive Care Med 2000;26:878-82.

22. Lorente L, Lecuona M, Jimenez A, Mora ML, Sierra A. Tracheal suction by closed system without daily change versus open system. Intensive Care Med 2006;32:538-44.

23. Lorente L, Lecuona M, Martin MM, Garcia C, Mora ML, Sierra A. Ventilator-associated pneumonia using a closed versus an open tracheal suction system. Crit Care Med 2005;33:115-9.

24. Rabitsch W, Kostler WJ, Fiebiger W, et al. Closed suctioning system reduces cross-contamination between bronchial system and gastric juices. Anesth Analg 2004;99:886-92.

25. Topeli A, Harmanci A, Cetinkaya Y, Akdeniz S, Unal S. Comparison of the effect of closed versus open endotracheal suction systems on the development of ventilator-associated pneumonia. J Hosp Infect 2004:58:14-9.

26. Niël-Weise BS, Snoeren RL, van den Broek PJ. Policies for endotracheal suctioning of patients receiving mechanical ventilation: A systematic review of randomized clinical trials. Infect Control Hosp Epidemiol 2007;28:531-6.

27. Lasocki S, Lu Q, Sartorius A, Fouillat D, Remerand F, Rouby JJ. Open and closed-circuit endotracheal suctioning in acute lung injury: Efficiency and effects on gas exchange. Anesthesiology 2006;104:39-47.

28. Lee CK, Ng KS, Tan SG, Ang R. Effect of different endotracheal suctioning systems on cardiorespiratory parameters of ventilated patients. Ann Acad Med Singapore 2001;30:239-44.

29. Darvas JA, Hawkins LG. The closed tracheal suction catheter: 24 hour or 48 hour change? Aust Crit Care 2002;16:86-8,90-2.

30. Quirke S. A comparative study of the incidence of nosocomial colonization in patients with closed suction catheter changes at 24 versus 48 hours. Crit Care III 1998;14:116,118-20.

31. Smulders K, van der Hoeven H, Weers-Pothoff I, VandenbrouckeGrauls C. A randomized clinical trial of intermittent subglottic secretion drainage in patients receiving mechanical ventilation. Chest 2002;121:858-62.
32. Girou E, Buu-Hoi A, Stephan F, et al. Airway colonization in longterm mechanically ventilated patients. Effect of semi-recumbent position and continuous subglottic suctioning. Intensive Care Med 2004:30:225-33.

33. Kollef MH, Skubas NJ, Sundt TM. A randomized clinical trial of continuous aspiration of subglottic secretions in cardiac surgery patients. Chest 1999;116:1339-46.

34. Siobal M, Kallet RH, Kraemer R, et al. Tracheal-innominate artery fistula caused by the endotracheal tube tip: case report and investigation of a fatal complication of prolonged intubation. Respir Care 2001;46:1012-8.

35. O'Neal PV, Munro CL, Grap MJ, Rausch SM. Subglottic secretion viscosity and evacuation efficiency. Biol Res Nurs 2007;8:202-9.

36. Leur JP, Zwaveling JH, Loef BG, Schans CP. Endotracheal suctioning versus minimally invasive airway suctioning in intubated patients: A prospective randomized controlled trial. Intensive Care Med 2003;29:426-32.

37. Leur JP, Zwaveling JH, Loef BG, Schans CP. Patient recollection of airway suctioning in the ICU: Routine versus a minimally invasive procedure. Intensive Care Med 2003;29:433-6.

38. Ji YR, Kim HS, Park JH. Instillation of normal saline before suctioning in patients with pneumonia. Yonsei Med J 2002;43:607-12.

39. Ackerman MH, Mick DJ. Instillation of normal saline before suctioning in patients with pulmonary infections: A prospective randomized controlled trial. Am J Crit Care 1998;7:261-6.

40. O'Neal PV, Grap MJ, Thompson C, Dudley W. Level of dyspnoea experienced in mechanically ventilated adults with and without saline instillation prior to endotracheal suctioning. Intensive Crit Care Nurs 2001;17:356-63.

41. Klockare M, Dufva A, Danielsson AM, et al. Comparison between direct humidification and nebulization of the respiratory tract at mechanical ventilation: Distribution of saline solution studied by gamma camera. J Clin Nurs 2006;15:301-7.

42. Leone M, Rousseau S, Avidan M. Target concentrations of remifentanil with propofol to blunt coughing during intubation, cuff inflation, and tracheal suctioning. Br J Anaesth 2004;93:660-3.

43. Leone M, Albanese J, Viviand X. The effects of remifentanil on endotracheal suctioning-induced increases in intracranial pressure in head-injured patients. Anesth Analg 2004;99:1193-8.

44. Brocas E, Dupont H, Paugam-Burtz C, Servin F, Mantz J, Desmonts JM. Bispectral index variations during tracheal suction in mechanically ventilated critically ill patients: Effects of alfentanil bolus. Intensive Care Med 2002;28:211-13.

45. Avidan MS, Zhang L, Burnside BA, et al. Anesthesia awareness and the bispectal index. N Engl J Med 2008;358:1097-1108.

46. Frass M, Dielacher C, Linkesch M, et al. Influence of potassium dichromate on tracheal secretions in critically ill patients. Chest 2005;127:936-41.

47. Brown M, Willms D. Colonization of Yankauer suction catheters with pathogenic organisms. Am J Infect Control 2005;33:483-5.

48. Sole ML, Poalillo FE, Byers JF, Ludy JE. Bacterial growth in secretions and on suctioning equipment of orally intubated patients: A pilot study. Am J Crit Care 2002;11:141-9.

49. Ng KS, Kumarasinghe G, Inglis TJ. Dissemination of respiratory secretions during tracheal tube suctioning in an intensive care unit. Ann Acad Med Singapore 1999;28:178-82.

50. Standards for All Health Care Facilities and Settings for high risk Respiratory Procedures Under Non-Outbreak Conditions, Ontario Ministry of Health, April 15, 2004.

51. Frengley RW, Closey DN, Sleigh JW, Torrance JM. The effect of closed system suction on airway pressures when using the Servo 300 ventilator. Crit Care Resusc 2001;3:230-5.

52. Stenqvist O, Lindgren S, Kárason S, Söndergaard S, Lundin S. Warning! Suctioning. A lung model evaluation of closed suctioning systems. Acta Anaesthesiol Scand 2001;45:167-72.

53. Vandenberg JT, Lutz RH, Vinson DR. Large-diameter suction system reduces oropharyngeal evacuation time. J Emerg Med 1999; 17:941-4. 


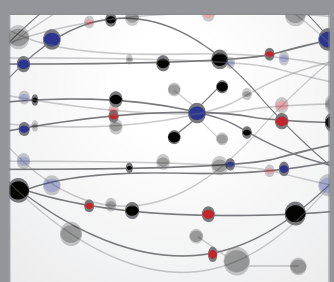

The Scientific World Journal
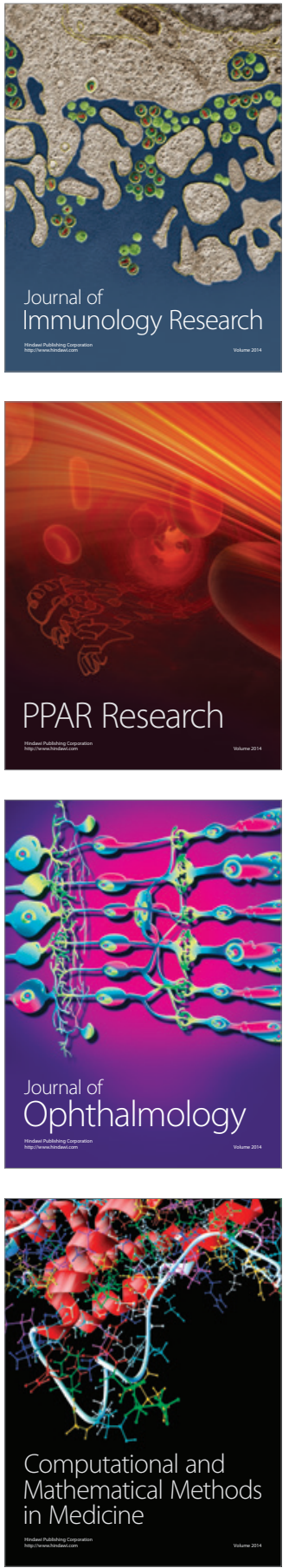

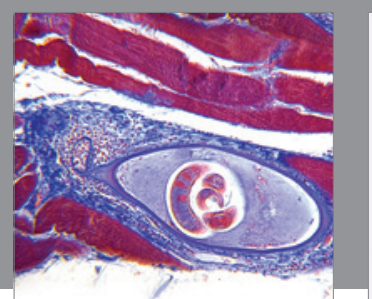

Gastroenterology Research and Practice

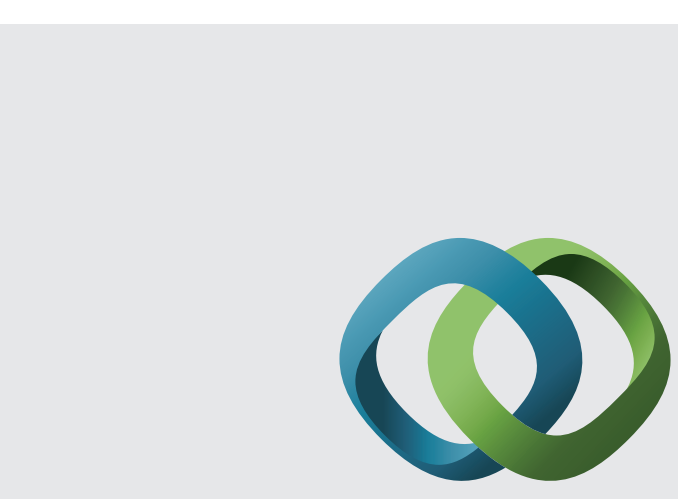

\section{Hindawi}

Submit your manuscripts at

http://www.hindawi.com
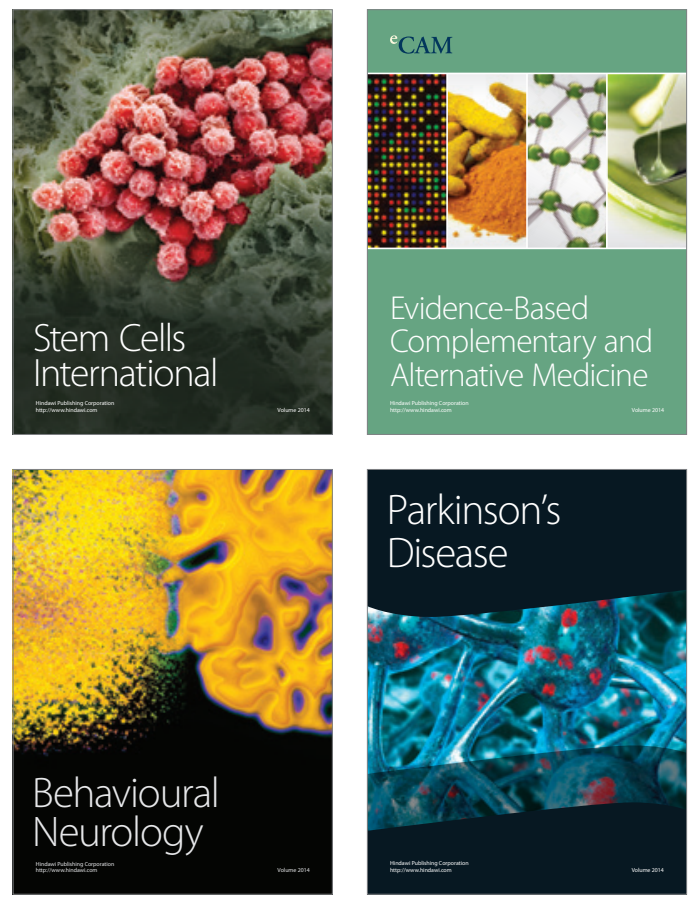
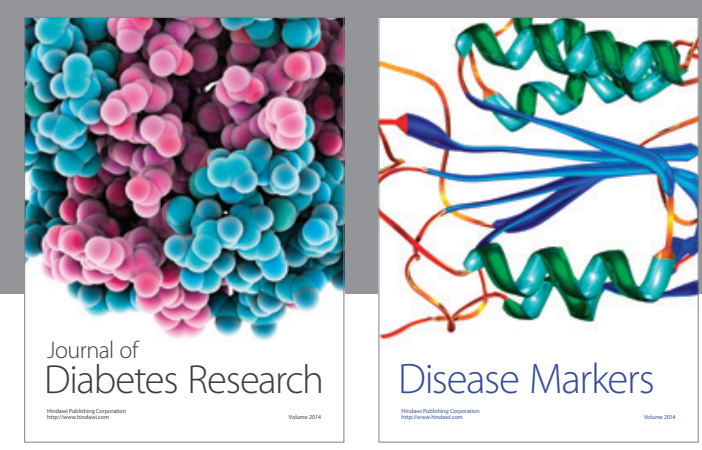

Disease Markers
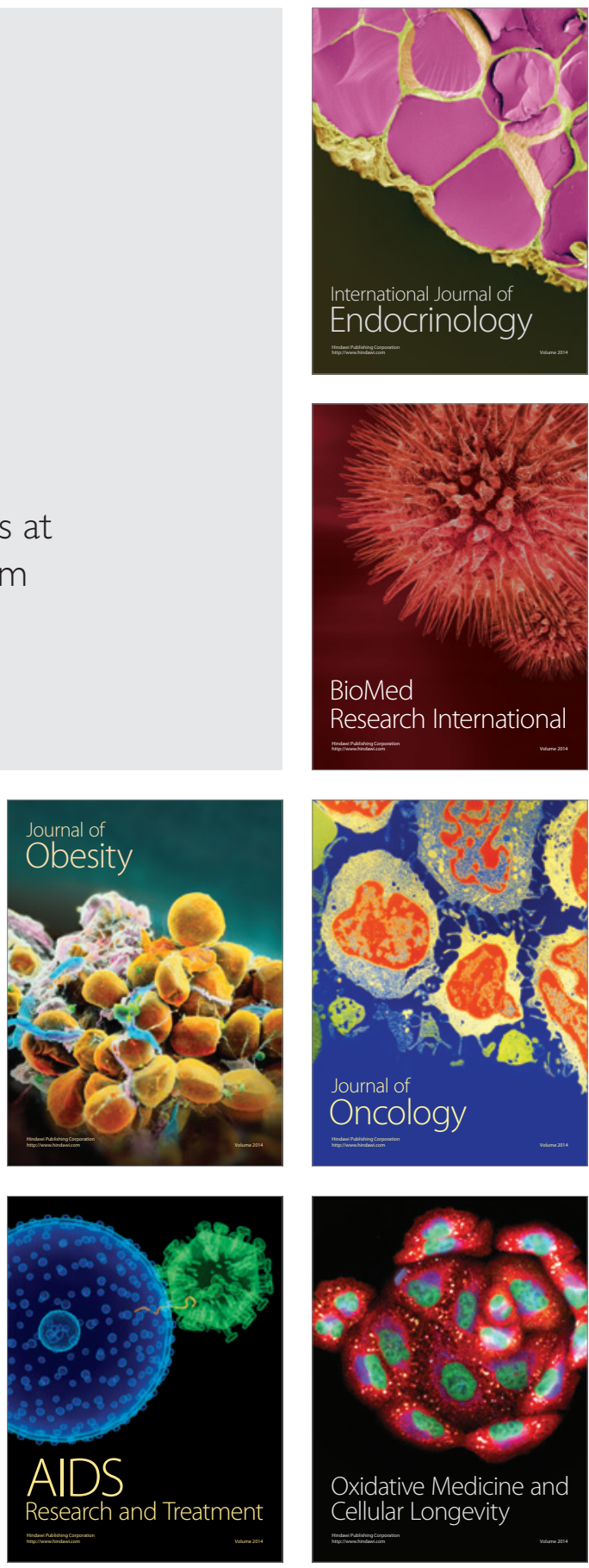